\title{
Соціологічне дослідження соціальної компетентності фахівців водного транспорту в контекстах завдань галузевої професійної освіти
}

\author{
Глебова Н. І., \\ Мелітопольський державний педагогічний університет імені Богдана Хмельницького
}

Розглянуті сучасні підходи до проблеми уніфікації в соціальній спрямованості професійної діяльності індивіда з іншими суб'єктами узгодження стандартів професійних взаємовідносин і розвитку соціальних середовищ. 3'ясовано актуальність завдання інтеграції навичок галузевого фахівця через розвиток соціальних компетентностей, встановлено специфіку «соціальності» як елемента фахових компетентностей, які забезпечують успішну діяльність галузевого професіонала. Виявлено тенденції переходу досліджень від режиму констатації і зіставлення галузевих і корпоративних стандартів «соціальних» компетентностей до теоретично обгрунтованих і емпіричним шляхом виявлених у ході багатофакторного аналізу оцінки й обліку суб'єктних складових соціальних норм у професійному середовищі. Проаналізована специфіка праці фахівців водного транспорту (морського вантажного флоту) в контексті галузевих професійних вимог і сучасних викликів. 3'ясовані соціологічні параметри залежностей і відповідностей культурно-світоглядно-мотиваційних чинників професійної діяльності від динаміки і якості процесу становлення професіонала. Висновується низка процесуальних ракурсів дослідження соціальних навичок і особистих якостей фахівця водного транспорту для комплексної оцінки взаємовпливів різнорідних чинників розвитку соціально значимих функцій в професійній діяльності. Обгрунтована потреба використання соціологічних засобів поглиблення знань, деталізації соціальних аспектів життєдіяльності, оптимального вибору методології емпіричного дослідження соціальної компетентності працівників цієї професійної групи та визначення напрямів наукового і професійно-освітнього супроводу ії розвитку.

Ключові слова: розвиток соціальних середовищ; фахова самореалізація професіонала; соціальна компетентність фахівця; фахівці водного транспорту; соціологічні методи дослідження; галузева професійна освіта

\section{The sociological research of the social competency of water transport specialists in the context of branch professional education targets}

\author{
Glebova N. I., Melitopol State Pedagogical University named after Bogdan Khmelnytsky
}

The modern social development stipulates for a need of unification in the social direction of individual's professional activity with other subjects and requires a qualitatively new level of the professional integration of individual's professional skills. The article deals with some modern approaches to the problem of the coordination of professional intercommunication standards and the development of social environments. The urgency of solving this target through the development of the branch specialist's social competencies and the integration of skills is cleared up; the peculiarity of «socialness» as an element of professional competencies, securing the branch expert's successful activity, is ascertained. Some tendencies of the transition of researches from the status of stating and comparing branch and corporative standards of «social» competencies to the assessment and registration of subjective components of social norms in the professional environment of different specific branches, theoretically proved and empirically revealed in the course of multifactor analysis, are shown. The specific character of the water transport (commercial fleet) specialists work in the context of branch professional demands and modern challenges is analyzed. Some sociological parameters of ascertaining the dependencies and correspondences of cultural, world-view and motivational factors from the dynamics and quality of the formation process of a professional are made clear. A number of processual foreshortenings concerning the development of social skills and personal qualities of the water transport specialist for performing his quite efficiently lined socially significant duties in the professional activity is concluded.

The necessity of using the sociological means of extending knowledge, of further detailing the social aspects of their vital functions, of optimal choosing a methodology of empiric research of the social competency of this professional group workers is substantiated.

Keywords: development of social environments; expert's professional self-realization; specialist's competency; water transport specialists; sociological methods of researching; branch professional education

\section{Социологическое исследование социальной компетентности специалистов водного транспорта в контекстах задач отраслевого профессионального образования}

\author{
Глебова Н. И., \\ Мелитопольский государственный педагогический университет имени Богдана Хмельницкого
}

Рассмотрены современные подходы к проблеме унификации в социальной направленности профессиональной деятельности индивида с другими субъектами согласования стандартов профессиональных взаимоотноше- 
ний и развития социальных сред. Выяснено актуальность задачи интеграции навыков отраслевого специалиста через развитие социальных компетенций, установлено специфику «социальности» как элемента профессиональных компетенций, обеспечивающих успешную деятельность отраслевого профессионала. Выявлены тенденции перехода исследований от режима констатации и сопоставления отраслевых и корпоративных стандартов «социальных» компетенций к теоретически обоснованным и эмпирически выявленным в ходе многофакторного анализа оценки и учета субъектных составляющих социальным нормам в профессиональной среде. Проанализирована специфика труда специалистов водного транспорта (морского грузового флота) в контексте отраслевых профессиональных требований и современных вызовов. Выяснены социологические параметры зависимостей и соответствий культурно-мировоззренчески-мотивационных факторов профессиональной деятельности от динамики и качества процесса становления профессионала. Обобщается ряд процессуальных ракурсов исследования социальных навыков и личных качеств специалиста водного транспорта для комплексной оценки взаимовлияния разнородных факторов развития социально значимых функций в профессиональной деятельности. Обоснована необходимость использования социологических способов углубления знаний, детализации социальных аспектов жизнедеятельности, оптимального выбора методологии эмпирического исследования социальной компетентности работников этой профессиональной группы и определение направлений научного и профессионально-образовательного сопровождения ее развития.

Ключевые слова: развитие социальных сред; профессиональная самореализация профессионала; социальная компетентность специалиста; специалисты водного транспорта; социологические методы исследования; отраслевое профессиональное образование

\section{Постановка проблеми.}

оціологічні виміри перспектив саморозвитку особистості в процесі навчання галузевих фахівців у контексті життєвих перспектив і самореалізації професіоналів різних галузей в Україні констатують однією 3 нагальних наукових проблем відсутність «цілісної картини майбутнього в складному суперечливому взаємозв'язку програмованих і очікуваних подій, 3 якими людина пов'язує соціальну цінність та індивідуальний сенс свого життя» [2, с. 38]. Перспектива особистості, як зауважує Є. Головаха, $є$ найважливішим чинником іiі розвитку й самореалізації, оскільки «особистість не отримує готової життєвої перспективи, а вибудовує іiї, змінюючи та уточнюючи впродовж життя, долаючи суперечливі альтернативи» [2, с. 38]. Соціальні взаємодії як чинник становлення i розвитку професійних груп сьогодні різною мірою є предметом аналізу соціології професії, соціології праці, а також економічної соціології (у контексті аналізу ринку праці) [4]. Розгляд еволюції соціологічних підходів різних наукових шкіл і теоретичних спрямувань дозволяє В. Погрібній виснувати, що сучасна професіоналізація $є$ «соціальним механізмом диференціації та спеціалізації», що «...функціонує як засіб розвитку змісту праці», в якому набувають великого значення професійна компетенція, етичний кодекс, механізм внутрішньо-професійного контролю, особливої професійної культури тощо» [12, с. 192]. Аналіз наукових праць засвідчує певні тенденції розробки проблеми: як виокремлення в предметному полі досліджень аспектів загально-гуманітарних, екологічних, культурологічних тощо, так і більш спеціалізованих, обумовлених галузевими потребами відповідності гуманістичним стандартам суспільного розвитку [19]. Окремі дослідження соціально значимих аспектів професіоналізації в сучасних умовах констатують значне відставання вивчення груп «соціотехнічних професій» від груп соціонімічних фахівців щодо якості взаємодії в колективі та соціальному середовищі загалом [16]. Однією 3 причин дослідники вбачають недостатню соціальну компетентність суб'єктів професійної діяльності, що походить від недостатнього опанування ними соціальних аспектів професії [23]. Таким чином, проблема діяльності фахівців морських професій у багатокультурному середовищі морського екіпажу актуалізує вироблення стандартів обов'язкової професійної культури фахівця з паспортом моряка, в широкому діапазоні - від соціально-психологічної до крос-культурної компетентності. Шляхом вирішення проблеми комплексного підходу може стати іï розгляд із залученням широкого спектру міждисциплінарних напрацювань академічної науки, зокрема соціології професій.

\section{Аналіз досліджень і публікацій.}

Соціологічні і соціально-психологічні ракурси взаємодії моряків у міжнародних екіпажах на даний час досить широко висвітлені в працях зарубіжних дослідників. Оособливостям багатонаціонального екіпажу присвячені праці Р. Бая і Г. Лемвіка, Н. Берга, О. Бруніла, Й.Сторгарда, Я. Хорка; проблема подолання комунікативних бар'єрів опрацьовувалась у працях Б. Ванг, М. Ямагучі; засоби і механізми розвитку емоційного інтелекту моряків розкрито в працях П. Болат, К. Кілік, Л. Тавакіоглу й інших; показники кореляції залежності аварійності на морських суднах i крос-культурних чинників та національної належності екіпажів досліджено в роботах С. Крістенсена, Л. Лаурсена, М. Фрайдберг.

Аналіз вказаних вище та інших досліджень останніх років, у яких пов'язується структура, зміст, специфіка професійної діяльності фахівців водного транспорту з розвитком іiї соціальних аспектів, дозволяє нам стверджувати значимість 
якомога ширшої системи знань про людину як індивіда, суб'єкта, особистості та індивідуальності у взаємодії з іншими індивідами, яка забезпечує його професійну ефективність в суб'єкт-суб'єктних відносинах. Важливими для нашого дослідження є дані про те, що:

- не тільки власний професійний розвиток, але й професійна галузева належність індивіда обумовлює структуру, функції і особливості його соціального розвитку;

- у процесі професійного розвитку фахівця, що здійснює діяльність в системах «людина-людина», процес набуття i опанування належних компетенцій значною мірою визначається рівнем розуміння, оцінки, осмислення соціальних аспектів професійної взаємодії, навиків поведінки та спілкування [1].

Метою дослідження $€$ аналіз відображених у науковій рефлексії підходів та обгрунтування актуальних напрямків соціологічного супроводу формування соціальної компетентності фахівців водного транспорту в процесі професійного навчання. Завданням роботи є обгрунтування потреби в комплексі соціологічних інтерпретацій проблеми розвитку соціальних функцій сучасного фахівця засобами галузевої професійної освіти.

Виклад основного матеріалу.

Відображені в низці грунтовних соціально-психологічних галузевих досліджень дані дозволяють характеризувати впливи на розвиток соціально-професійної групи працівників водного транспорту декількома специфічними чинниками: «особливим» характером умов праці; перебуванням морських фахівців в умовах відносної соціальної ізоляції (й у відриві від звичного берегового середовища); обмеженням перебування морських фахівців у рейсі визначеними термінами; особливостями управління колективом (субординація, статутна система відносин); нерозділеністю побутової та виробничої сфер життєдіяльності тощо $[3 ; 7]$.

В. Крутецький до основних компонентів самореалізації професіонала зараховує:

1) наявність здібностей людини до опанування конкретної професії з сукупністю професійно-важливих якостей, необхідних для виконання завдань;

2) успішність набуття професійних знань, умінь і навичок, які сприяють професійному становленню майбутнього фахівця [5].

Згідно $з$ дослідженням Я. Хорка, комунікативні навички моряків характеризуються наступними складовими: побудова команди (лідерство), співіснування, підтримка інших, емпатія тощо [20]. Важливим чинником вбачаємо обгрунтування професійної придатності адаптивними здібностями і підходами до процесу адаптації, перебіг якого зумовлюється впливом професійної діяльності на формування особистості та можливістю особистості змінювати процес цієї діяльності. Окремо для даної категорії фахівців зазначимо проблеми, пов'язані як із переглядом галузевих нормативних цінностей, так і з серйозними неузгодженостями між нормами і цілями певної, в тому числі професійної, культури і соціально сформованими здібностями членів групи діяти згідно з ними. На думку Я. Хорка, окрім суто психологічних компонентів особистісної компетентності, обов'язковим компонентом є розвиток у майбутніх моряків культурної сенситивності - знання та повага до норм інших культур, оскільки розуміння причин певної поведінки, обумовлене культурними особливостями, дозволяє вибудувати адекватне ситуації сприйняття поведінки іншої людини та правильну реакцію на неї в різних ситуаціях життєдіяльності моряка. Оскільки професійна культура має видиму і приховану частину, культурна сенситивність - єдиний шлях до розуміння логіки носія певної культури для інших членів екіпажу [20]. Зауважимо, що висновки деяких досліджень щодо зниження рівня дискримінації та етнічних розбіжностей при більшому етнічному розмаїтті членів екіпажу [21] дають змогу розглядати національне різноманіття морського екіпажу як цілком позитивне явище за умови розвинених навиків і знань для якісної професійної та культурної комунікації екіпажу. Звідси випливає актуальність набуття майбутніми моряками навичок адекватного міжнаціонального спілкування, знань особливостей культури та побуту, особливостей менталітету моряків іншої національності для досягнення успішного повсякденного спілкування та ефективного виконання своїх посадових обов'язків.

У контексті багатоманіття чинників впливу і засобів професійного зростання, в тому числі засобів неформальної освіти, актуальності набуває сучасний соціологічний дискурс взаємодії суспільства та професійної освіти, що визначає проблему неявних впливів культурних середовищ i суб'єктів соціокультурної взаємодії як особливу соціальну практику (сукупність специфічних комунікацій i взаємодій, способів узгодження i оформлення соціальних смислів і дій), в межах якої формуються певні габітуси соціально орієнтованої свідомості фахівців (як диспозиції, що породжують і структурують практику носія певного знання, його уявлень і орієнтацій в соціальному просторі) [10, с. 21]. I. Нечитайло зараховує комунікативну специфіку неявних впливів культурних середовищ до чинників трансляції «певних цінностей, установок та принципів соціальної взаємодії», що відбувається шляхом «структурування знань, що транслюються, та організацію складових, елементів освітнього середовища на- 
вчального закладу, для засвоєння фахівцями «соціальних ролей, очікуваних та / або нав'язуваних суспільством». [10, с. 17-18]. Таким чином, соціологічні інтерпретації дозволяють системно брати до уваги соціальні аспекти професійної освіти «як особливої форми соціальної взаємодії, що «утворюють неформальну складову освітньої практики» і виконують «соціалізуючі й відтворюючі функції» в процесах селекції, регуляції та соціального контролю в галузевій професійній освіті. Не менш важливим висновком соціологічного підходу до предмету є те, що структурне єднання, що забезпечується комунікацією як процесом формування й вчасних змін установок на актуальні смисли, на розуміння соціальної реальності і загалом виступає процесом формування компетенцій (професійних, загальнокультурних, соціальних тощо» $[10$, с. 21$]$, може істотним чином змінювати картину взаємодії суб'єктів у соціальному, навчальному, культурному тощо полях, структура яких «являє навчальні, культурні, моральні та інші практики [10, с. 25].

Висновки ряду педагогічних дисертаційних досліджень, присвячених формуванню професійних навичок моряків (див., наприклад: [6; 12; 14]), стверджують, що у професійно-освітньому середовищі процедури вимірювання параметрів певної «соціальної компетентності» неминуче орієнтуються на певний сегмент вивчення соціо-культурного універсуму людини. Як ми вже зауважували, акмеологічні співвідношення розглянутих чинників формування професіоналізму дозволяють прогнозувати перспективи не тільки досягнення високих професійних результатів, але і в ширшому сенсі - успішність реалізації професіонала, тобто впливи професійно-психологічної організації особистості на ставлення людини до праці і самооцінки своїх професійно важливих якостей. У цьому аспекті соціологічний підхід має опиратись на розрізнення у психології професій двох сторін професіоналізму: стану мотиваційної сфери людини (мотиви, смисли, цілі, задоволеність працею) і стану операційної сфери (прийоми, засоби діяльності, здібності, знання, вміння, навички) [7].

Результати авторських глибинних інтерв'ю 3 представниками морських професій [1] дозволяють нам стверджувати, що до особливостей і проблемних площин своєї професійної страти фахівцями морського транспорту зараховуються:

- високі вимоги до професійної підготовки, мобільності, культурної і мовної адаптивності, здатності до перенесення значних психологічних навантажень, соціокультурної толерантності тощо;

- соціальна й психологічна адаптація на березі, відсутність координованої державою підтримки українських громадян - працівників іноземних компаній у разі потреби, відсутність державної моделі їх пенсійного забезпечення тощо;

- значні труднощі соціально-психологічного й морального характеру, пов'язані з облаштуванням ïх сімей, вихованням дітей тощо, що пов'язується, насамперед, зі специфікою праці в морі - довготривалими рейсами;

- психологічна специфіка довготривалого перебування в закритому просторі, комунікативні особливості праці в корабельному колективі;

- потреба розвинених практичних навичок управління людьми різних культур і формування в колективі атмосфери цілковитої професійної довіри до колег і підлеглих.

Разом із тим респонденти засвідчили, що попри високий рівень зарплати, високими є такі мотиваційні особливості внутрішнього світу людей своєї професійної страти, як схильність до пізнання навколишнього світу, внутрішня ментальна причетність до певної культури «людей моря», проблема повної невизначеності щодо професійної самореалізації на Батьківщині у даний період.

Дослідження професійного становлення моряків у системі освітнього процесу вказують, що, 3 одного боку, різноманітність атрибутивних зв'язків компонентів соціальної і професійної свідомості особистості в різних сферах застосування важливих навичок настільки значна, що хоча вони наскрізно проникають i взаємозумовлюють досліджувані структурні рівні суспільної та індивідуальної свідомості особистості в надзвичайно широкому спектрі $[11$, с. 68; 16], з іншого - далеко не завжди можливо охопити їх методологічно й інструментально засобами послідовного поєднання різних існуючих підходів [13, с. 353-359]. Відтак, аналіз міждисциплінарних досліджень та розгляд соціально-психологічних особливостей морських міжнародних екіпажів у низці галузевих досліджень $[3 ; 5 ; 7 ; 16 ; 17-18 ; 21-22]$, вказує на потребу системного підходу 3 виокремленням наступних компонентів структури дослідження професійної соціалізації майбутнього моряка:

- змістовно-процесуального (міжкультурний, стратегічний і когнітивний аспекти);

- мотиваційно-цільовий;

- морально-соціальний.

Перспективними напрямками практичних соціологічних досліджень професійної страти фахівців водного транспорту на даному етапі роботи вбачається застосування широкого спектру засобів оцінки успішності професійної діяльності галузевого фахівця та їх залежності від:

- впливів чинника мотивації у виборі морської професії;

- впливів навчальних форм і засобів набуття професійно-важливих соціальних якостей; 
- впливів професійної мобільності та адаптивності фахівців морського транспорту на успішність їх діяльності;

- впливів соціально-культурних чинників становлення галузевих фахівців водного транспорту на динаміку їх професійної деформації;

- впливів комунікативної специфіки галузевого професійного середовища на розвиток професійної культури фахівця водного транспорту;

- впливів упровадження системи соціальних стандартів якості професійного навчання у вітчизняних галузевих навчальних закладах.

Більшість дослідників професійної освіти моряків обгрунтовує необхідність більш змістовного наповнення дисциплін «Менеджмент морських ресурсів», «Безпека життєдіяльності» соціальною компонентою формування у майбутніх офіцерів лідерських якостей, соціально-комунікативних навичок роботи в екіпажі в умовах дотримання галузевих стандартів і процедур у прийнятті рішень [7], а також формування особистісно-значимих індивідуальних професійних характеристик в умовах довготривалого плавання [3].

Вивчення впливів впровадження системи стандартів якості у галузевих навчальних закладах, на нашу думку, є актуальним у контексті необхідної післядипломної освіти галузевих фахівців, що пов'язуються 3 високими вимогами до професійної підготовки, мобільності і соціальної адаптивності фахівців морських професій в умовах глобалізаційних процесів [9].

Зазначимо, що специфіка працевлаштування моряків визначається низкою документів: законодавчих актів; нормативів трудових відносин, які регулюються ринком і міжнародними стандартами; Міжнародною конвенцією по підготовці, дипломуванню моряків та несення вахти (STSW 1978); Конвенцією про працю в морському судноплавстві (MLC 2006). На сьогоднішній день, згідно наказу МОНМС України «Про впровадження системи стандартів якості в учбових закладах освіти, підпорядкованих Міністерству освіти і науки, молоді та спорту, які здійснюють підготовку кадрів для екіпажів морських суден» від 09.12.2011 р. № 1411 [9], керівники відповідних структур зобов'язані забезпечити впровадження системи стандартів якості відповідно до вимог правила 1/8 Міжнародної конвенції ПДНВ.

Дослідниками проблеми підготовки фахівців морської галузі на засадах компетентнісного підходу [15;16] встановлено, що сьогодні в упровадженні та використанні стандартів підготовки морських фахівців $\epsilon$ певні недоліки, зокрема у процесі підготовки фахівців морської галузі більшість навчальних дисциплін циклів викладається без належної узгодженості і належного врахування практичного значення навчального матеріалу, його впливу на формування реальних навичок. Хоча людський чинник, в першу чергу практичні навички взаємодії в команді, згідно думки дослідників, підтверджений кваліфікацією і компетентністю моряків, стає головним критерієм у забезпеченні безпеки судноплавства [8]. Для випускників українських закладів підготовки фахівців водного транспорту проблема адаптації значною мірою обумовлена також сучасною крюїнговою політикою морських компаній, націлених на пошук дешевої робочої сили, в результаті чого більшість екіпажів світового флоту стали змішаними за національністю, мовними та культурними о3наками [8]. Дані інтерв'ювання представників трьох крюїнгових компаній: «Vi Ship Ukraine», «Acomarine» i «Alpha Navigation» (м. Одеса), засвідчують вказані вище тенденції і підтверджують наявність змін у міжнародній морській індустрії щодо формування екіпажів, що має знайти відображення в підготовці кадрів для морського та річкового транспорту України як учасниці Міжнародної морської організації (IMO) [8]. Відтак, в контексті нашого дослідження слід вести мову про специфіку діяльності фахівця морської професії не тільки як про можливість людини справно виконувати свої певні трудові функції, не тільки про достатню міру іiї інтеграції з іншими людьми, тобто не тільки ії відповідність деяким вимогам (параметрами), але і про здатність фахівця компенсувати відсутні в специфічному середовищі фрагменти соціальної реальності розширенням власних соціальних компетентностей як засобу, способу і методу вирішення професійних завдань і власного професійного саморозвитку.

\section{Висновки.}

Аналіз дослідження чинників професійного становлення і освітніх аспектів розвитку компетентностей фахівців водного транспорту, дозволяе нам виснувати, що:

- в традиційних підходах до професійної підготовки галузевих фахівців водно-транспортних спеціальностей існує дефіцит спеціальної соціально-компетентнісної підготовки через недостатню визначеність і структурованість у підходах до проблеми, а також належного наукового супроводу особистісних психологічних та культурних аспектів розвитку індивіда в процесі їх підготовки до професійної діяльності;

соціокультурні аспекти в практиці досліджень фахівців морських професій значно менше беруться до уваги як функціональні складові соціально-професійної компетентності і майже цілковито нівелюються процесуальними і технологічними обумовами професійної реалізації в ринкових умовах;

- соціальні компетентності як сталі компоненти збереження особистісних і соціалізаційних 
потенцій фахівця мають стати предметом соціологічного розгляду, розробки прикладних соціологічних методик та їх застосування в освітній практиці для подальшої продуктивної професійної самореалізації особистості.

Соціологічна проблема на етапі дослідження, на нашу думку, полягає, насамперед, у встановленні параметрів якості зворотного зв'язку на рівні верифікації особистісних компетентнісних інтенцій досліджуваних категорій фахівців. Актуальною проблемою є встановлення залежностей і відповідностей культурно-світоглядно-мотиваційних чинників від динаміки і якості процесу станов- лення професіонала. Прикладні аспекти такого дослідження потребують обгрунтування розглянутих соціальних чинників у якості елементів концепції формування цілісності соціального та індивідуального світу професіонала в сучасних умовах.

Важливим завданням соціології є дослідження динаміки базових соціалізаційних характеристик процесу становлення галузевого професіонала i їx використання для координації процесів формування внутрішніх мотиваційних чинників професійного зростання і становлення соціальних та професійних компетенцій особистості фахівця засобами професійної освіти.

\section{БІБІЛІОГРАФІЧНІ ПОСИЛАННЯ}

1. Глебова Н. І. Засади дослідження соціокультурного феномену «Людина моря» в контексті соціологічних практик / Н. І. Глебова // Вісник Маріупольського держ. ун-ту. Серія: Філософія, культурологія, соціологія. - 2016. - № 12. - С. 54-67.

2. Е. И. Головаха. Жизненная перспектива и профессиональное самоопределение молодежи / Е. И.Головаха. Київ: Наук. думка, 1988. - 142 с.

3. Истомина О. А. Морские экипажи: опыт социально-психологического изучения / О. А. Истомина, М. Ю. Орлова. - Владивосток: Мор. гос. ун-т, 2005. - 142 с.

4. Ксенофонтова Е. Социология компетентности и модель компетенций как области научного и практического интереса / Е. Ксенофонтова, Н. Пехова // Вестник Моск. ун-та. Серия 18: Социология и политология. - 2014. - № 1. - С. 194-206.

5. Крутецкий В. А. Психология способностей моряков / В. А. Крутецкий. - М.: Просвещение, 2003. - 352 с.

6. Кулакова М. В. Формування готовності до професійної діяльності в майбутніх фахівців у вищих морських навчальних закладах: дис. ... канд. пед. наук: 13.00.04 / М. В. Кулакова. - Одеса: Південно-український держ. пед. ун-т ім. К. Д. Ушинського, 2006. - 225 с.

7. Лобастов В. М. Психологические основы безопасности судовождения: учеб. пособие / В. М. Лобастов. - Владивосток: ДВВИМУ им. адм. Г. И. Невельского, 1980. - 52 с.

8. Міусов М. Університет «далекого плавання»/ М. Міусов // День. - 2016. - № 67-68. - С. 17.

9. Наказ Міністерства освіти і науки, молоді та спорту України № 1411 від 09.12.2011 р. «Про впровадження системи стандартів якості у навчальних закладах, підпорядкованих Міністерству освіти і науки, молоді та спорту, що здійснюють підготовку кадрів для екіпажів морських суден». - Режим доступу: http://osvita.ua/legislation/ Vishya osvita/25775/

10. Нечитайло I. С. Системно-кодова концепція взаємодії суспільства та освіти: автореф. дис. ... д-ра соціол. наук: 22.00 .04 / I. С. Нечитайло. - Київ: Київський нац. ун-т ім. Т. Шевченка, 2017. - 39 с.

11. Онищук В. М. Професійне становлення моряків в системі освітнього процесу / В. М. Онищук // Соціально-економічні, соціально-педагогічні та соціально-психологічні проблеми морської освіти: Матеріали I Міжнародної наук.-практ. конф. (Керч, 14-16 червня 2012 р.). - Керч; Мелітополь: Колор Принт, 2012. - С. 66-71.

12. Погрібна В. Л. Соціологія професіоналізму: монографія / В. Л. Погрібна. - Київ: Алерта: КНТ: ЦУЛ, 2008. $336 \mathrm{c.}$

13. Попова О. П. Особливості професійної діяльності майбутніх судноводіїв і сутність їх професійної компетентності / О. П. Попова // Педагогіка формування творчої особистості у вищій і загальноосвітній школах: зб. наук. праць. - Запоріжжя, 2011. - № 17. - С. 353-359.

14. Сокол I. В. Формування професійної компетентності судноводіїв у процесі вивчення фахових дисциплін: дис. ... канд. пед. наук: 13.00 .04 / І. В. Сокол. - Херсон, 2011. - 265 с.

15. Тирон О. М. Психолого-педагогічні основи формування іншомовної компетентності майбутніх моряків: дис. ... канд. психол. наук: 19.00.07 / О. М. Тирон. - Київ: Відкритий міжнар. ун-т розвитку людини «Україна», 2016. $-284 \mathrm{c}$.

16. Черненко Н. І. Педагогічні умови реалізації андрагогічного підходу у професійній підготовці робітників морського транспорту: дис. ... канд.. пед.. наук: 13.00.04 / Н. І. Черненко. - Херсон, 2016. - Режим доступу: www. kspu.edu/FileDownload.ashx/Diss_Chernenro.pdf?id=8b71e90a..

17. Чигрин В. А. Отчет по результатам опроса студентов КГМТУ (Керчь, апрель 2011 г.) / В. А. Чигрин. - Керчь: КГМТУ, 2011. - $128 \mathrm{c}$.

18. Шафран Л. М. Теория и практика профессионального психофизического отбора моряков / Л. М. Шафран, Э. М. Псядло. - Одесса: Феникс, 2008. - 292 с.

19. Dunning D. Why people fail to recognize their own incompetence / D. Dunning, K. Johnson, J. Ehrlinger, J. Kruger // Current Directions in Psychological Science. - 2003. - № 12, № 3. - P. 83-87. 
20. Horck J. Cultural and gender diversities affecting the ship/port interface / J. Horck. - Bremen: ISPIC, $2008 .-18$ p. 21. Kahveci E. Transnational Seafarer Communities / E. Kahveci, T. Lane, H. Sampson. - Cardiff University, 2002. Retrieved from: http://www.sirc.cf.ac.uk/6_Multinational_Crews .aspx

22. Kilic K. Influence of Emotional Intelligence on the Work Performance of Seafarers / K. Kilic, L. Tavacioglu, P. Bolat; T. Neumann (ed.) // Marine Navigation and Safety of Sea Transportation STCW, Maritime Education and Training (MET), Human Resources and Crew Manning, Maritime Policy, Logistics and Economic Matters. - CRC Press, 2013. P. 169-174.

23. Kruger J. Unskilled and Unaware of It: How Difficulties in Recognizing One's Own Incompetence Lead to Inflated Self-Assessments / J. Kruger, D. Dunning // Journal of Personality and Social Psychology. - 1999. - № 77, № 6. - P. 1121-1134.

\section{REFERENCES}

1. Ghlebova, N.I.(2016).Zasady doslidzhennja sociokuljturnogho fenomenu «Ljudyna morja» vkonteksti sociologhichnykh praktyk [Principles of the study of the socio-cultural phenomenon «The Man of the Sea» in the context of sociological practices]. Bulletin of Mariupol State University. Philosophy, Cultural Studies, Sociology, 12 [in Ukrainian].

2. Gholovakha, E.Y. (1988). Zhyznennaja perspektyva y professyonaljnoe samoopredelenye molodezhy [Life Perspective and Professional Self-Determination of Youth]. Kyiv [in Russian].

3. Ystomyna, O.A., \& Orlova, M.Ju. (2005). Morskie jekipazhi: opyt social'no-psihologicheskogo izuchenija [Marine crews: the experience of socio-psychological study]. Vladyvostok: Mor. ghos. un-t [in Russian].

4. Ksenofontova, E., \& Pekhova, N. (2014). Socyologhyja kompetentnosty y modelj kompetencyj kak oblasty nauchnogho y praktycheskogho ynteresa [Sociology of competence and model of competences as areas of scientific and practical interest]. Bulletin of Moscow. University. Sociology and Political Science, 1, 194-206 [in Russian].

5. Kruteckyj, V.A. (2003). Psykhologhyja sposobnostej morjakov [Psychology of seafarers' abilities]. Moscow: Prosveshhenye [in Russian].

6. Kulakova, M.V. (2006). Formuvannja ghotovnosti do profesijnoji dijaljnosti v majbutnikh fakhivciv u vyshhykh morsjkykh navchaljnykh zakladakh [Formation of readiness for professional activity of future specialists in higher marine educational establishments]. Candidate's thesis. Odesa [in Ukrainian].

7. Lobastov, V.M. (1980). Psykhologhycheskye osnovy bezopasnosty sudovozhdenyja [Psychological basis of navigation safety] Vladyvostok: DVVIMU im. adm. G. I. Nevel'skogo [in Russian].

8. Miusov, M. (2016). «Universytet «dalekogho plavannja» [University of «long-distance»]. Day, 67-68, 17 [in Ukrainian]. 9. Nakaz Ministerstva osvity i nauky, molodi ta sportu Ukrajiny № 1411 vid 09.12.2011 r. «Pro vprovadzhennja systemy standartiv jakosti u navchaljnykh zakladakh, pidporjadkovanykh Ministerstvu osvity $i$ nauky, molodi ta sportu, shho zdijsnjujutj pidghotovku kadriv dlja ekipazhiv morsjkykh suden» [Order of the Ministry of Education and Science, Youth and Sports of Ukraine № 1411 of 09.12.2011 "On the introduction of a system of quality standards in educational institutions subordinated to the Ministry of Education and Science, Youth and Sports, which provide training for crews of sea vessels»]. Retrieved from: http://osvita.ua/legislation/Vishya_osvita/25775/ [in Ukrainian].

10. Nechytajlo, I.S. (2017). Systemno-kodova koncepcija vzajemodiji suspiljstva ta osvity [System-code concept of the interaction of society and education]. Extended abstract of Doctor's thesis. Kyiv [in Ukrainian].

11. Onyshhuk, V.M. (2012). Profesijne stanovlennja morjakiv v systemi osvitnjogho procesu [Professional formation of sailors in the educational process]. Socialjno-ekonomichni, socialjno-pedaghoghichni ta socialjno-psykhologhichni problemy morsjkoji osvity - Socio-economic, socio-pedagogical and socio-psychological problems of marine education: Proceedings of the 1-st International Scientific and Practical Conference, (pp. 66-71). Kerch; Melitopolj: Kolor Print [in Ukrainian].

12. Poghribna, V.L. (2008). Sociologhija profesionalizmu [Sociology of professionalism]. Kyiv: Alerta: KNT: CUL

13. Popova, O.P. (2011). Osoblyvosti profesijnoji dijaljnosti majbutnikh sudnovodijiv i sutnistj jikh profesijnoji kompetentnosti [Features of professional activity of future ship drivers and the essence of their professional competence]. Pedagogy of formation of a creative person in higher and secondary schools, 17, 353-359 [in Ukrainian].

14. Sokol, I.V. (2011). Formuvannja profesijnoji kompetentnosti sudnovodijiv u procesi vyvchennja fakhovykh dyscyplin [Formation of professional competence of ship drivers in the process of studying professional disciplines]. Candidate's thesis. Kherson [in Ukrainian].

15. Tyron, O.M. (2016). Psykhologho-pedaghoghichni osnovy formuvannja inshomovnoji kompetentnosti majbutnikh morjakiv [Psychological and pedagogical bases of formation of foreign competence of future sailors]. Candidate's thesis. Kyiv [in Ukrainian].

16. Chernenko, N.I. (2014). Pedagogichni umovy` realizaciyi andragogichnogo pidxodu u profesijnij pidgotovci robitny kiv mors `kogo transportu [Pedagogical conditions of the implementation of the andragogical approach in the professional training of marine transport workers]. Candidate's thesis. Retrieved from: www.kspu.edu/FileDownload. ashx/Diss_Chernenro.pdf?id=8b71e90a [in Ukrainian].

17. Chyghryn, V.A. (2011). Otchet po rezuljtatam oprosa studentov KGMTU [A report on the results of the survey of students of the KGMTU]. Kerch: KGMTU [in Russian].

18. Shafran, L.M., \& Pjsadlo, E.M. (2008). Teoryja y praktyka professyonaljnogho psykhofyzycheskogho otbora morjakov [Theory and practice of professional psychophysical selection of seamen]. Odessa: Fenyks [in Russian]. 
19. Dunning, D., Johnson, K., Ehrlinger, J., \& Kruger, J. (2003). Why people fail to recognize their own incompetence. Current Directions in Psychological Science, 12 (3), 83-87.

20. Horck, J. (2008). Cultural and gender diversities affecting the ship/port interface. Bremen: ISPIC.

21. Kahveci, E., Lane, T., \& Sampson, H. (2002). Transnational Seafarer Communities Cardiff University. Retrieved from: http:// www. sirc. cf. ac. uk/6 Multinational Crews .aspx

22. Kilic, K., Tavacioglu, L., \& Bolat, P. (2013). Influence of Emotional Intelligence on the Work Performance of Seafarers. Marine Navigation and Safety of Sea Transportation STCW, Maritime Education and Training (MET), Human Resources and Crew Manning, Maritime Policy, Logistics and Economic Matters Edited by Tomasz Neumann. CRC Press.

23. Kruger, J., \& Dunning, D. (1999). Unskilled and Unaware of It: How Difficulties in Recognizing One's Own Incompetence Lead to Inflated Self-Assessments. Journal of Personality and Social Psychology, 77, 6, $1121-1134$.

\section{Глебова Наталя Іванівна}

Кандидат соціологічних наук, доцент

Мелітопольський державний педагогічний університет імені Богдана Хмельницького

72312, м. Мелітополь, вул. Гетьманська, 20

\section{Glebova Natalia}

$\mathrm{PhD}$ in Sociology, Assoc. Prof.

Melitopol State Pedagogical University named after Bogdan Khmelnitsky

20, Getmanska St., 72312, Melitopol, Ukraine

Email: nat.glebova2005@gmail.com

Цитування: Глебова Н. І. Соціологічне дослідження соціальної компетентності фахівців водного транспорту в контекстах завдань галузевої професійної освіти / Н. І. Глебова // Науково-теоретичний альманах «Грані». - 2018. - Т. 21. - № 3. - С. 25-32

Citation: Glebova, N.I. (2018). Sotsiolohichne doslidzhennia sotsialnoi kompetentnosti fakhivtsiv vodnoho transportu $\mathrm{v}$ kontekstakh zavdan haluzevoi profesiinoi osvity [The sociological research of the social competency of water transport specialists in the context of branch professional education targets]. Scientific and theoretical almanac «Grani», 21(3), 25-32. 